\title{
Study on the Main Characteristics and Development Countermeasures of Creative Tourism
}

\author{
Yurong Zhang \\ School of Humanities, Chongqing Jiaotong University, Chongqing 400074, China \\ yurong_zhang@126.com
}

\begin{abstract}
In recent years, with the rapid development of cultural and creative industries, creative economic rises rapidly. The integration and development of tourism and cultural creative industry is an inevitable choice under the background of creative economy. Creative tourism is a new tourism form based on the integration of tourism and cultural creative industry. As a special tourism form, creative tourism gradually became the focus of UNESCO and the world tourism organization, thus many countries pay more attention to the development of it. Firstly, this paper expounds the concept of creative tourism. Secondly, it was pointed out that creative tourism has the characteristics of the following five aspects: distinctive culture, unique creativity, novel experience, powerful fusion and sustainable development. Finally, the development countermeasures of creative tourism were proposed from three aspects of the government, tourism enterprises and universities.

Index Terms - Creative tourism; Tourism management, Main characteristics, Development countermeasures, Creative Tourism Talent.
\end{abstract}

\section{Introduction}

With the rapid development of global economy, creative industry is rising rapidly. Since 1990, new concept such as creative industry, creative city and creative nation appeared in succession, creative development strategy adopted by many countries in the whole world.

With the development of social economy and the acceleration of globalization, environmental problems and social problems became more prominent. Thus, people began to reflect the social development mode and gradually realized that the social, cultural and other non-economic factors especially the cultural factors play an important role in economic activities. Culture is considered to be an important resource for economic development in the post-industrial society, cultural turn has gradually become an important trend of the whole society.

The traditional development mode of tourism industry has no longer meet the requirements of the times, the transformation of tourism industry has become an inevitable tendency. Under the background, creative tourism develop rapidly in recent years. Creative tourism has fundamentally break the bondage of traditional thinking, so it can be good for achieving regional economic and cultural appreciation. The development of creative tourism can also be good for integrating tourism resources and promoting its sustainable development.

\section{Concept of Creative Tourism}

The concept of creative tourism was first proposed by the New Zealand scholar Richard and Raymond in 2000. They made the following definition of creative Tourism: Creative tourism is a kind of tourism products for tourists to learn culture or skill of destination country or community in the process of tourism. Creative tourism is good for tourists to understand the local residents and experience tourism destination atmosphere through participation in interactive studio, developing their creative potential and so on. The concept of creative tourism described the target and form of tourism and then it emphasized the importance of interaction to creative tourism.

According to document index, there are different understanding of creative tourism in China. Professor Li Wuwei pointed out that creative tourism was a new mode to integrate tourism resources. The development of creative tourism was good to innovate tourism product and forge the tourism industry chain. He defined the creative tourism from the angle of industry and emphasized the multidimensional integration of various resources, the guidance for the trend of tourist consumption and the extension of industrial. Zhou Yun and Feng Xuegang thought that creative tourism was a tourism product and its core element was creative interaction between tourists and tourism destination. It was good for tourists to enrich knowledge, improve skills, develop individual creative potential and then get a personalized experience. Zhao Yuzhong put forward the core elements of creative tourism. He argued that the basis of creative tourism was culture and the cultural resources were the material. Cultural consumption and experience was the driving force of creative tourism, interactive learning and experience was the path to creative tourism. Finally, he pointed out that the targets of creative tourism were tourists' self development and the economic and socially development of destination.

To sum up, the creative tourism can be defined from the aspect of destination. As we all know that the core of creative tourism is creative communication and experience. Therefore, the creative tourism products must contain the tourist interaction on tourism experience. It can make tourists to fulfill cultural self-awareness and creation and then acquire their unique tourism experience. Creative tourism is not a simple combination of creative and tourism, but a new develop mode for the growing spiritual and cultural needs of tourists and the sustainable development of tourism. 


\section{Main Characteristics of Creative Tourism}

\section{A. Cultural Characteristic}

As the foundation and platform for creative tourism, culture is the core element of creative tourism. Creative tourism exists under a certain cultural background. Cultural characteristic is one of the main characteristics of creative tourism, it is helpful for tourists to acquire different cultural experience. The cultural characteristic of creative tourism is reflected in the pursuit for the tourist cultural elements it contains, but also reflected in the cultural interaction of tourism activities.

The cultural characteristic can be reflected in the creative tourism products. For example, the British royal family culture attract a lot of tourist all over the world. Buckingham Palace, Windsor Castle and Westminster Abbey have become the most popular scenery of London. At the same time, the British drama culture is also very famous. Shakespare is the most famous dramatist, so many tourists go to London to appreciate Shakespare's classic drama.

In addition, there are many museums in London. According to incomplete statistics, London has about more than 200 museums. It's the precious cultural tourism resources of creative tourism. As we all know that the British Museum is the world famous museum. The British Museum has a lot of precious cultural relics from all over the world. The British Museum use many modern technologies to protect and display cultural relics so that visitors can have a better understanding of the history and the value of cultural relics.

\section{B. Unique Innovation}

From ancient to modern times, people's consumption demand and aesthetic standards always changed with the change of times. The driving force which maintains the sustainable development of any kind of commercial patterns must be creativity and innovation, otherwise it is difficult to form a strong vitality. Although creativity can have a variety of interpretation, but the usual concept of creative is an unique method of thinking and solving problem or comprehensive knowledge used in the field of new problems. Creativity and innovation often give us a dynamic and constantly changing and innovation. Creative tourism is relying on people's inspiration and imagination. It often promotes the traditional tourism resources and mode by means of art, science and technology and then gets the competitive advantage to beyond other competitors by variable tourism products .

Innovation is one of the most important characteristics of creative tourism. For example, "series of impression" directed by Zhang Yimou attracts more and more people in recent years. The key factor of its success is changing the traditional program form. People often appreciate programs in theater, but Zhang Yimou devoted to the innovation of traditional program by changing places and outstanding cultural elements by modern technology. "Impression Liu Sanjie" is the first new concept of "landscape subject-live performance". It's a revolution in performance including unique set of performances, art, shocking and nationality. Traditional performance is often played in theater, and the impression of
Liu Sanjie performances construct the virtual stage in nature. It's the world's largest landscape theatre with twelve peaks as the background by the Lijiang River in a radius of two kilometres of Yangshuo. The centre stage includes the beautiful water of the Lijiang River and Guilin Mountains which gives people a broad perspective and special feeling. Thus people can immerse in the beautiful scenery of Yangshuo and acquire impressed experience.

Similar with the Impression of Liu Sanjie, the famous show of "Impression Wulong" also caused great concern to the media and then attracted more and more people. "Impression Wulong" theatre locates in a mysterious canyon of Chongqing Wulong. The canyon has a "U" shape and the scenery is very beautiful. The theater is not only protect the ecological, but also provide excellent performance space for the show. The theater is designed and installed about 2700 seats for the audience. The stage extends to the stand, so the actors and the audience can close contact. In the "impression Wulong" show, more than 100 featured actor participate in the performance. The main content of the show is endangered "Chuanjiang Haozi". "Impression Wulong" let the audience experience the magnificent natural landscape of natural heritage and deeply understand the unique local customs of Bashu earth in the 70 minutes show. It's also a new form to protect the intangible cultural heritage.

\section{Novel Experience}

With the development of experience economy, tourists would like to participate in tourism activities more than to be a observer of culture. Different from the lower participation of traditional sightseeing and leisure tourism, creative tourism pays more attention to the unique and participation for tourists. It encourages people to seek special experience which can make them have a novel personalized experience.

Experience is the main form of creative tourism. With the increasingly rich experience, tourists' consumption become increasingly mature. Tourist would like to pursuit tourism experience such as more intense pursuit of personalized, stimulation, leisure and satisfaction of tourism experience. Creative tourism encourages tourists to participate in all kinds of activities, emphasizes communication and learning between tourists and tourist destination, closer the distance between tourists and tourist destination. Different from experience, creative tourism not only needs to experience, but also inspire tourists' potential in the process of the experience, show the creative potential, create personal feelings, imagination and wisdom. In the tourism experience, tourists can acquire some skills and knowledge or personal feeling, so the creative tourism is a higher level of experience tourism.

With the development of experience economy, the potential experience demand of tourists was motivated. More and more tourists pay attention to tourism experience, so more tourism experience products need to be supplied by tourism enterprises. Tourists can participate in various creative activities and acquire special individual experience in the progress of creative tourism. Creative tourism can not only satisfy tourists experience demand, but also strengthen tourists self-confidence. 
Creative tourism is an important national strategy in New Zealand. There are many novel festivals in New Zealand each year and attract more and more tourists all over the world. For example, the music and art festival of New Zealand is a world famous festival and many musicians and artists come to New Zealand to attend the special festival. In addition, Maori is the indigenous inhabitants in New Zealand and Maori culture is very mysterious for many people. Kawhia Food Festival is held every year by a fishing village which is on the west coast of kawhia. Lots of tourists come here to experience traditional Maori food and Maori culture.

\section{Powerful Fusion}

Cultural creative tourism has strong integration features. Because creative can penetrate into the culture, art, economy, science and technology, so creative tourism has powerful fusion. Creative tourism can promote the development of regional economy. In addition, creative integration of all kinds of cultural resources including historical and cultural resources, cultural resources, cultural resources of commercial industry, social and cultural resources, forming a new culture can be accepted by the majority of people and it is also be good to cultural inheritance, development and innovation.

The fusion of creative tourism includes integration of industries and products. For example, cosmic tourism is the integration of tourism industry and cosmic tourism and movie tourism is the integration of tourism industry and movie industry. Meanwhile, creative element can be found in the whole process of creative tourism.

The history of creative tourism in foreign countries is longer than China. There are five Disney theme parks all over the world, which locates in the California and Florida of the United States, Tokyo of Japan, Paris of France and Hongkong of China. Disney theme park which was built in 1955 is the earliest theme park of the world. It's a successful model of the integration of cosmic industry and tourism industry. Disney theme parks make good use of cosmic resources and created a fantastic world and takes advantages as times goes by. Shanghai Disney theme park started construction in 2011 and is expected to be completed in 2015. Maybe it will become the famous tourist attraction and attract a lot of visitors.

In recent years, the tendency of tourism industry and movie industry is more obvious. There are many scenery which are famous for a successful film and attract many tourist each year. For example, many tourists go to Rome because of a romantic film named "Roman Holiday". The love story of the princess and reporters in "Roman Holiday" attracts many lovers to visit Rome. Meanwhile, many tourists go to New Zealand to appreciate its beautiful scenery and fascinating culture. Today, the filmmaking process is longer and post-production has grown more sophisticated as the industry matures. Wellington is also building a studio named Weta. Weta is opened to tourists and people can get deep understanding of the film post-production. By the integration of tourism industry and movie industry, the movie tourism gradually wins more and more tourists.

\section{E. Sustainable Development}

We all know that resources is limited but creativity is unlimited, so one of the important characteristic of creative tourism is the sustainable development. Because human intelligence resources -- creative ability has been in a rising state, so the travel content and mode of creative tourism can update and develop infinitely. Creative tourism can also make good use of intangible resources including culture, history, brand, design, craft or symbols.

\section{Development Countermeasures of Creative Tourism}

\section{A. Strengthen Government's Efforts to Support the Creative Tourism}

In order to promote the development of Creative Tourism, the government should take the following five measures. Firstly, the government should cultivate creative life environment, construct and improve tourism infrastructure and actively introduce advanced foreign idea. Secondly, the government should pay more attention to the development of Museum and creative park, so the tourists can deepen the understanding of creative tourism and participate in the creative activities positively. Thirdly, the government should not only provide theoretical and technical support for the development of creative industry enterprises but also provide financial support for outstanding creative achievements in practice of small and medium-sized tourism enterprises. In addition, the government should focus on the introduction and cultivation of creative talents and promote the cooperation of tourism industry and creative industry. Finally, the government should protect tourism creative achievements by establishing and improving the intellectual property rights, laws and regulations of trademark and patent. Through the above measures, the government can create better conditions for the development of creative tourism.

\section{B. Strengthen the Development of Creative Tourism Product}

Fundamentally, the development of creative tourism is to meet the personalized tourism needs and experience tourism demand. Tourism consumers want to be able to participate in tourism activities such as learning skills, participating in artistic creation, attending creative class and so on, thus they could have a deeper understanding of culture and history of local residents. Therefore, the tourism enterprises should strengthen the development of creative tourism product by the means of deeply developing the cultural resources and making comprehensive use of the cultural resources of destination.

Through the development of culture, creative products can enhance cultural appeal and carry out various forms of creative tourism experience. So it's very important to promote the creative development of culture and the experience innovation. Therefore, the creative tourism should create the experience for the tourists from the aspects of sensory organs, emotion, thought and behavior. By the overall design of the tourist products, the creative tourism can be better meet the needs of tourists. 


\section{Strengthen the Cultivation of Creative Tourism Talents}

University is an important base for cultivating creative tourism talents. In the background of creative tourism, colleges should further strengthen efforts to cultivate tourism creative talents.

Tourism majors in colleges and universities need to reform in the following aspects. Firstly, because training scheme occupies an important position in the major of tourism, so tourism majors in colleges and universities should pay more attention to revise training scheme. In the core target, creative tourism talents should be the core target. Secondly, in the curriculum, creative quality should be placed in an important position. Thirdly, various teaching method such as group learning, case studies, lectures and other forms of heuristic teaching should be used in class. In practice, we should strengthen the construction of research base and cultivate talents by cooperating with enterprises. Finally, on the construction of teaching staff, we should strengthen the cultivation and introduction of innovative teaching. At the same time, colleges and universities should strengthen association with tourism enterprises and cultural creative enterprises by hiring business elites as visiting professor or inviting elites to hold lecture.D. Powerful Fusion

Cultural creative tourism has strong integration features. Use either SI (MKS) or CGS as primary units. (SI units are encouraged.) English units may be used as secondary units (in parentheses). An exception would be the use of English units as identifiers in trade, such as "3.5-inch disk drive."

Avoid combining SI and CGS units, such as current in amperes and magnetic field in oersteds. This often leads to confusion because equations do not balance dimensionally. If you must use mixed units, clearly state the units for each quantity that you use in an equation.

\section{Conclusion}

Creative tourism is a new mode with the development of tourism industry, which takes culture as the main content and takes creative talents for the productivity. It has strong vitality and it can also satisfy tourists personalized tourism demand and can impressed tourists.

Creative tourism will put creative elements into the whole process of tourism, to promote the integration of creative industry, to inject new vitality into the tourism industry and then strengthen the linkage development of the tourism industry and other industries.

This paper analyzes the concept and characteristic of creative tourism. The thesis pointed out that creative tourism is a new tourism form based on the integration of tourism and cultural creative industry. Then five main characteristic including distinctive culture, unique creativity, novel experience, strong integration and sustainable development are proposed. To promote the development of creative tourism, the government should take more efforts to support the creative tourism and the tourism enterprises should strengthen the development of creative tourism. In addition, universities and colleges should strengthen the cultivation of creative tourism talents.

\section{Acknowledgment}

This paper is supported by the National Social Science Fund Project " Empirical research on the cultural and creative industry fusion mechanism under the tourism creative economic background" (11CJY081), Education and Teaching Reform Project of Chongqing " Study on the training model of tourism creative talents under the view of creative tourism in Chongqing universities"(112052), Education and Teaching Reform Project of Chongqing Jiaotong University " Research on the training model of tourism creative talents in tourism majority under the view of creative tourism" (1201005), Soft Science Project of Chongqing " Empirical research on the cultural and creative industry fusion mechanism in Chongqing under the tourism creative economy background " (cstc2012cx-rkxA00027) .

\section{References}

[1] W. Marian. Cities as creative spaces for cultural tourism: a plea for the consideration of history, tourism cultural, vol.8, pp. 17-26, 2010.

[2] S. Carlisle, M. Kunc, E. Jones and S. Tiffin, Supporting innovation for tourism development through multi-stakeholder approaches: Experiences from Africa, Tourism Management, vol.35, pp.59-69, 2013.

[3] E. Redaelli, Analyzing the "creative city" governance: relational processes in Columbus,, City, Culture and Society, vol.2, pp. 85-91, 2011.

[4] S. Chaperon and B. Brmwell, Dependency and agency in peripheral tourism development, Annals of Tourism Research, vol.40, pp. 132-154, 2013.

[5] A. Coghlan and K. Filo, Using constant comparison method and qualitative data to understand participants' experiences at the nexus of tourism, sport and charity events, Tourism Management, vol.35, pp.122131,2013

[6] J.S. Horng, S.F. Chou, C.H. Liu and C.Y. Tsai, Creative, aestetics and eco-friendliness: A physical dining environment design synthetic assessment model of innovative restaurant, Tourism Management, vol.36, pp.15-25, 2013.

[7] A. Rydzik, A. Pritchard, N. Morgan and D. Sedgley, The potential of arts-based transformative research, Annals of Tourism Research, vol.40, pp. 283-305, 2013.

[8] G. Richards, Creative and tourism, Annals of Tourism Research, vol.38, pp. 1225-1253, 2011.

[9] T. Winter, Rethinking tourism in Asia, Annals of Tourism Research, vol.34, pp. 27-44, 2007

[10] R.A. Woldoff, T. Decola and R.C Litchfield, The aspirational creative class: urban residential preferences of college students in creative majors, City, Culture and Society, vol.2, pp. 75-83, 2011.

[11] R. Russell and B. Faulkner, Entrepreneurship, chaos and the tourism area life cycle, Annals of Tourism Research, vol.31, pp. 556-579, 2004.

[12] C. Raymond, Creative tourism new Zealand, www.fuel4arts.com, 2003.

[13] M. Bontje and S. Musterd. Creative industries, creative class and competitiveness: expert opinions critically appraised, Geoforum40, pp. 843-852, 2009.

[14] X. Matteucci, Photo elicitation: Exploring tourist experiences with research-found images, Tourism Management, vol.35, pp.190-197, 2013.

[15] R. Prince. Fleshing out expertise: the making of creative industries experts in the united kingdom, Geoforum41, pp. 875-884, 2010.

[16] G. Richards and J. Wilson, Developing creativity in tourist experiences: A solution to the serial reproduction of culture, Tourism Management, vol.27, pp.1209-1223, 2006.

[17] D.F Li. The education characteristics of tourism management master of surrey in UK, Journal of henna institute of education, vol.25, pp. 132134, 2006. 